\title{
Structure and composition of the benthic macroinvertebrate community on wetland and irrigated rice cultivation
}

\author{
Estrutura e composição da comunidade de macroinvertebrados \\ bentônicos de área úmida e lavouras de arroz irrigado
}

Karen Tavares Juruá ${ }^{1}$, Isadora Adamoli Pagel ${ }^{2}$, Vitor Emanuel Tavares ${ }^{1}$ and

\section{Lilian Terezinha Winckler Sosinski ${ }^{3}$}

\author{
${ }^{1}$ Programa de Pós-graduação em Manejo e Conservação do Solo e da Água - PPG MACSA, Faculdade de \\ Agronomia Eliseu Maciel - FAEM, Universidade Federal de Pelotas - UFPel, \\ CEP 96010-900, Pelotas, RS, Brazil \\ e-mail: karentj@gmail.com; vtavares@ufpel.edu.br \\ ${ }^{2}$ Programa de Pós-graduaçáo em Ecologia - PPG Ecologia, Universidade Federal do Rio Grande do Sul - UFRGS, \\ CEP 91501-970, Porto Alegre, RS, Brazil \\ e-mail: isadorapagel@gmail.com \\ ${ }^{3}$ EMBRAPA Clima Temperado, CEP 96011-971, Pelotas, RS, Brazil \\ e-mail: lilian.sosinski@embrapa.br
}

\begin{abstract}
Wetlands are environmentally and economically important ecosystems. The irrigated rice crops are considered artificial wetlands, because they offer food and refuge to different aquatic communities. The benthic macroinvertebrates are used to study environmental quality. The knowledge from the organisms which inhabit the natural and artificial wetlands can help to verify less harmful management practices in the agroecosystems. Aim: The aim of this research was to analyze and compare the benthic macroinvertebrate community from a wetland and an experimental kind of rice cultivation. Methods: It was used dip nets $1 \mathrm{~mm}$ mesh every 15 days, with six repetitions in each place, from January to March 2010. After washing and screening them in the laboratory, the organisms were identified using stereoscope microscope and identification keys, and classified according to their functional trophic group. Results: The whole organisms collected were 33,293 specimens. It was found 34 taxa, being 26 founded in the rice crops and 31 on the wetland. The natural wetland shows greater abundance, being responsible for $90.47 \%$ from the total abundance in this study. In the rice crop the abundance and the richness increased in the course of collection. However, it did not reach the values founded in the wetlands during the cultivation period. The most found groups in the two environmental were Belostomatidae and Planorbidae, while Hyalellidae and Elmidae were found only in the wetland, being a stress indicator in the wetland. Conclusions: The community structure including abundance, richness and composition was statistical different between wetlands and rice cultivation.
\end{abstract}

Keywords: natural wetlands, benthic macroinvertebrate, trophic functional groups, artificial wetland, impact.

Resumo: Áreas úmidas são ecossistemas de importância ambiental e econômica. As lavouras de arroz irrigado são consideradas áreas úmidas artificiais, pois fornecem alimento e abrigo para diferentes comunidades aquáticas. Os macroinvertebrados bentônicos vêm sendo amplamente utilizados como ferramenta para estudos de qualidade ambiental. O conhecimento dos organismos que habitam as áreas úmidas naturais e artificiais pode auxiliar na verificação de práticas de manejo menos impactantes nesses agrossistemas. Objetivo: O objetivo desta pesquisa foi analisar e comparar a comunidade de macroinvertebrados bentônicos de uma área de úmida natural (banhado) e uma lavoura experimental de arroz irrigado. Métodos: Foram realizadas coletas com rede de máo com malha de $1 \mathrm{~mm}$ a cada 15 dias, com seis repetiçóes em cada local, durante o período janeiro de 2010 a março de 2010. Resultados: Foi coletado um total de 33.293 indivíduos. Quanto à riqueza, foram encontrados um total de 34 táxons, sendo 26 destes encontrados na lavoura e 31 no banhado. $\mathrm{O}$ banhado apresentou maior abundância, totalizando $90,47 \%$ dela. Na lavoura, tanto a abundância quanto a riqueza aumentaram sucessivamente no decorrer das coletas, porém não atingindo os valores encontrados no banhado, durante o período de cultivo. Os grupos mais encontrados nos dois ambientes 
foram organismos da família Belostomatidae e Planorbidae. Hyalellidae e Elmidae apareceram somente no banhado, podendo ser um indicador do grau de impacto nesses agroecossistemas. Conclusóes: Através das análises estatísticas pôde ser observada uma diferença significativa na estrutura da comunidade, incluindo abundância, riqueza e composição, nas amostras do banhado e da lavoura.

Palavras-chave: áreas úmidas naturais, macroinvertebrados bentônicos, grupos funcionais tróficos, áreas úmidas artificiais, impactos.

\section{Introduction}

Wetlands are important ecosystems, highly productive and with high biological diversity, being considered of high priority conservation. These ecosystems are suffering anthropic modifications being converted to agriculture and livestock, for example. The knowledge about ecological process that are modified by the activities developed in these sites can subsidy decision making about the uses and management that offer preservation to this process.

In the wetlands, the irrigated rice cultivation causes modifications, listed by Chomenko (1997), such as reduction of natural ecosystems; variation of groundwater; compaction, reduced porosity and soil salinization, water supply shortage. These impacts, together with the use of agrotoxic could change the water quality and sometimes could exceed the ecosystem resilience. Given that, it would be impossible to sustain the biota that lives in wetland and adjacent habitat.

Despite harmful, this is a very important crop, being the Rio Grande do Sul state one of the most important rice producer at Brazil, with $1,050,000$ ha with this cultivation, producing about 6,000 kg.ha ${ }^{-1}$, corresponding to $50 \%$ of Brazilian rice producing (IRGA, 2006). The southern zone of Rio Grande do Sul is responsible for $16.6 \%$ of rice crop area from the state, which means 171,555 ha (IRGA, 2006). These regions municipalities show big plains with a greater part of these soils with limited drainage and flood plains as in the municipality of Capão do Leão (27.91\%) and Rio Grande (69.0\%) (Winckler-Sosinski, 2009), which makes it easy the flood irrigation used to these crops. Although the anthropic alterations, the rice crops are environmental that have ecological functions because they are used to host a lot of organisms, both shelter and food as for reproduction. These crops are considered, according to Ramsar Convention (2006), artificial wetlands.

Studies focusing on the biota that are found in these areas are fundamental to create alternative management practices to mitigate the impact in these ecosystem's biological structure and function.
Benthic macroinvertebrates are easy to collect and have relative easy identification, having diversified responses to different levels of disturbance, reflecting the state of the whole aquatic ecosystem (Reice and Wohlenberg, 1993). Furthermore, the trophic guilds provide relevant information about the ecosystem function and may be affected by habitat availability and other changes in the ecosystems (Callisto et al., 2001). The characterization of the wetland and rice cultivation communities allows us to understand the changes imposed by human disturbance, and provides knowledge about the crop management dispensed, subsidy information which provides sustainable use in artificial wetlands.

The aim of this study was to characterize and compare taxonomically and functionally the benthic macroinvertebrate community presented in artificial and natural wetlands in the extreme south of Brazil.

\section{Material and Methods}

The samples were collected in a wetland from the São Gonçalo Channel system and in experimental rice plots cultivation ( $\left.31^{\circ} 52^{\prime} 00^{\prime \prime} \mathrm{S}, 52^{\circ} 21^{\prime} 24^{\prime \prime} \mathrm{W}\right)$, both of them located at Estação Experimental Terras Baixas (EETB) from Embrapa Temperate Climate, at the Capão do Leão municipality, at Rio Grande do Sul state. The experimental plots were $180 \mathrm{~m}^{2}$, with the convectional management according SOSBAI (2007), and approximately $15 \mathrm{~cm}$ of flood water. It was sown with Fronteira seed at November 13, 2009. The fertilizer application was $300 \mathrm{~kg} / \mathrm{ha}$ from NPK (01-25-25).

The wetland is approximately 1500 ha (Pinheiro and Dias, 1998). The samples were collected in the delimited area by nets at the same area as the rice cultivation $\left(180 \mathrm{~m}^{2}\right)$, at sites with approximately the same water depth $(15 \mathrm{~cm})$, this being measured by a ruler.

All samplings occurred from January to March 2010, coinciding with the period of rice cultivation, totalizing six samplings in each environment. The samplings were conducted on January $(01 / 14$, 01/27), February (02/11, 02/26) and March (03/15 and 03/31). The sampling effort was with four people with dip nets with $1 \mathrm{~mm}$ mesh traversing the 
crop and the wetland for 20 minutes. The sampled organisms were sent to the ecotoxicology and biomonitoring laboratory at EETB, where screening was done and the specimens was preserved at alcohol $70 \%$. After this, the organisms were identified until the last taxonomic level that was possible and grouped according the trophic functional groups (TFG) according Stenert (2009), Copatti (2010) and Costa (2006).

During the sampling $\mathrm{pH}$, conductivity and temperature was verified with digital $\mathrm{pHmeter}$ Digimed model DM2P, digital conductivimeter Digimed DM3P and mercury thermometer, respectively.

The randomization test using Euclidean distance was done using software MULTIV v2.4.2 (Pillar and Orlóci, 1996) to verify composition, richness, abundance and TFG differences between rice cultivation and wetland.

\section{Results}

The abiotic information of water was presented in Table 1 . The conductivity was always higher in the wetland than in the rice cultivation.

There were found 33,293 organisms, being the wetland responsible for $90.47 \%$ of the abundance of total collected organisms. It is possible to observe statistical differences in richness $(\mathrm{p}=0.029)$, abundance $(\mathrm{p}=0.028)$ and benthic macroinvertebrate composition $(\mathrm{p}=0.03)$ between wetland and rice cultivation.

The most abundant organisms were Belostomatidae (7.265 specimens), followed by Planorbidae (6.427 specimens), which occurred mainly at wetland. Physidae was the only group that occurred exclusively in the rice cultivation.

34 taxa were found, 26 at the rice cultivation and 31 at the wetland (Table 2). Hyalellidae and Elmidae were presented only at the wetland.

It was observed a successively increased in abundance and richness during the sampling period (Figure 1), mainly in rice cultivation.
The organisms were divided at six trophic functional groups according to their food category: predator, generalist, shredder, collector, scraper and parasite (Figure 2). The randomization test presented significant differences $(\mathrm{p}=0.033)$ at TFG when compared wetland to rice cultivation. Among the benthic macroinvertebrate found at the rice cultivation, the shredders and scrapers have participated much less than in wetland.

\section{Discussion}

Wetlands are rich in humic compounds and low levels of $\mathrm{pH}$ and can present high values of electric conductivity, according to Esteves (1998). Santos (2008) states that the wetland conductivity positively influences some animal communities.

The increasing abundance along the sampling period in wetland and rice cultivation can be explained by the system hidroperiod. In March, the abundance of wetlands has a slightly decrease compared to the previous month, while in rice cultivation it still increases. This increase could be explained by the colonization that is occurring at this environmental once the rice crops are flood since December. However, this abundance did not reach the wetlands values during the cultivation period that reach only four or five months).

The Hyalellidae and Elmidae family were presented only at the wetland probably due to the degree of interference at rice crops and it may being an indicator of the degree of impact at these agroecosystems, while the Physidae family can establish population at this kind of artificial environment.

Compared to the study presented by Perera (2010), using near sample areas, it is possible to notice similarities in the richness values founded in this study to different environment. However, there are different community composition, being observed representatives of other groups such as Ostracoda, Acari, Trichoptera e Plecoptera that not occurred in this study, except the first one

Table 1. Abiotic water parameter analyzed during the collection period.

\begin{tabular}{|c|c|c|c|c|c|c|}
\hline \multirow[b]{2}{*}{ Month } & \multicolumn{3}{|c|}{ Wetland } & \multicolumn{3}{|c|}{ Rice Cultivation } \\
\hline & $\mathrm{pH}$ & $\begin{array}{c}\text { Conductivity } \\
\left(\mu \mathrm{s} . \mathrm{cm}^{-1}\right)\end{array}$ & $\begin{array}{c}\text { Temperature } \\
\left({ }^{\circ} \mathrm{C}\right)\end{array}$ & $\mathrm{pH}$ & $\begin{array}{l}\text { Conductivity } \\
\left(\mu \mathrm{s} . \mathrm{cm}^{-1}\right)\end{array}$ & $\begin{array}{c}\text { Temperature } \\
\left({ }^{\circ} \mathrm{C}\right)\end{array}$ \\
\hline January & 5.55 & 184.15 & 26.55 & 5.95 & 77.15 & 27.30 \\
\hline Standard Deviation & 0.21 & 23.83 & 2.19 & 0.07 & 11.38 & 0.42 \\
\hline February & 6.15 & 153.50 & 30.20 & 6.70 & 45.30 & 27.95 \\
\hline Standard Deviation & 0.07 & 89.80 & 4.53 & 0.00 & 5.23 & 5.02 \\
\hline March & 6.45 & 119.25 & 27.60 & 8.00 & 86.60 & 27.60 \\
\hline Standard Deviation & 1.34 & 11.38 & 1.13 & 0.99 & 17.82 & 4.95 \\
\hline
\end{tabular}


Table 2. Abundance of collected organisms at wetland (Wet) and rice cultivation (Ric).

\begin{tabular}{|c|c|c|c|c|c|c|c|c|c|c|c|c|c|}
\hline \multirow{2}{*}{ Taxa* } & \multicolumn{2}{|c|}{ Collect 1} & \multicolumn{2}{|c|}{ Collect 2} & \multicolumn{2}{|c|}{ Collect 3} & \multicolumn{2}{|c|}{ Collect 4} & \multicolumn{2}{|c|}{ Collect 5} & \multicolumn{2}{|c|}{ Collect 6} & \multirow{2}{*}{ Total } \\
\hline & Ric & Wet & Ric & Wet & Ric & Wet & Ric & Wet & Ric & Wet & Ric & Wet & \\
\hline Gastropoda & - & - & - & - & - & - & - & - & - & - & - & - & - \\
\hline Ampularidae (Sc) & - & 4 & - & 2 & - & 3 & - & - & 15 & 6 & 51 & 7 & 88 \\
\hline Planorbidae (Sc) & - & 1251 & 8 & 393 & - & 427 & 1 & 2034 & - & 1481 & 4 & 828 & 6427 \\
\hline Physidae (Sc) & 11 & - & 12 & - & 7 & - & 181 & - & 104 & - & 208 & - & 523 \\
\hline Hirudinida (Pa) & - & - & - & 18 & - & - & - & 11 & 1 & 1 & 2 & - & 33 \\
\hline Oligochaeta (C) & 1 & - & 1 & - & - & - & - & - & - & - & - & - & 2 \\
\hline Ostracoda (G) & - & 1 & 2 & - & - & - & - & - & - & - & - & - & 3 \\
\hline Amphipoda & - & - & - & - & - & - & - & - & - & - & - & - & - \\
\hline Hyalellidae (C) & - & 62 & - & 76 & - & 3 & - & 27 & - & 7 & - & 13 & 188 \\
\hline Ephemeroptera & - & - & - & - & - & - & - & - & - & - & - & - & - \\
\hline Baetidae (Sc) & - & 618 & - & 682 & - & 60 & - & 24 & 7 & 61 & 27 & 7 & 1486 \\
\hline Caenidae (C) & - & 140 & - & 17 & - & 8 & 47 & 304 & 20 & 508 & 128 & 416 & 1588 \\
\hline Odonata & - & - & - & - & - & - & - & - & - & - & - & - & - \\
\hline Aeshnidae (Pr) & - & - & - & 6 & - & 1 & - & - & - & 2 & 1 & - & 10 \\
\hline Libellulidae (Pr) & 16 & 87 & 4 & 107 & 30 & 197 & 131 & 139 & 73 & 251 & 255 & 969 & 2259 \\
\hline Protoneuridae (Pr) & - & 22 & 7 & 130 & 16 & 232 & 55 & 381 & 64 & 168 & 92 & 57 & 1224 \\
\hline Hemiptera & - & - & - & - & - & - & - & - & - & - & - & - & - \\
\hline Belostomatidae (Pr) & 44 & 220 & 21 & 727 & 19 & 1470 & 37 & 1519 & 45 & 2178 & 55 & 930 & 7265 \\
\hline Corixidae (G) & - & 172 & 5 & 17 & 5 & 1 & 10 & 10 & 45 & 30 & 31 & 8 & 334 \\
\hline Mesoveliidae (Pr) & 1 & - & - & - & - & - & - & - & - & - & - & 1 & 2 \\
\hline Nepidae (Pr) & - & - & - & - & - & - & - & 1 & - & - & - & - & 1 \\
\hline Notonectidae (Pr) & 3 & 192 & 4 & 64 & 27 & 2 & 21 & 23 & 12 & 16 & 13 & 27 & 404 \\
\hline Coleoptera & - & - & - & - & - & - & - & - & - & - & - & - & - \\
\hline Curculionidae (Sh) & - & - & - & - & - & - & 3 & 75 & - & - & - & 1 & 79 \\
\hline Dryopidae (G) & - & 4 & - & - & - & - & - & - & - & - & - & 1 & 5 \\
\hline Dysticidae (Pr) & 2 & - & 1 & 1 & 6 & 1 & 3 & 6 & 1 & - & 4 & 15 & 40 \\
\hline Elmidae (C) & - & 9 & - & 1 & - & 10 & - & 1 & - & 2 & - & - & 23 \\
\hline Gyrinidae (Pr) & - & 2 & 1 & 2 & - & - & - & - & - & - & - & - & 5 \\
\hline Haliplidae (Pr) & - & - & - & - & - & 13 & 1 & 18 & - & 5 & - & 4 & 41 \\
\hline Hydrochidae (Sh) & - & 3 & - & - & - & - & - & - & - & - & - & - & 3 \\
\hline Hydrophilidae (G) & 2 & 97 & 4 & 200 & 3 & 88 & 3 & 47 & 3 & 53 & 8 & 30 & 538 \\
\hline Noteridae (G) & - & - & - & - & - & 4 & - & 26 & - & 24 & - & 30 & 84 \\
\hline Diptera & - & - & - & - & - & - & - & - & - & - & - & - & - \\
\hline Chironomidae (G) & - & 122 & 31 & 51 & 60 & 22 & 77 & 686 & 295 & 136 & 617 & 2003 & 4100 \\
\hline Chaboridae (Pr) & - & 1 & - & - & - & - & - & 1 & - & 8 & - & 30 & 40 \\
\hline Psychodidae (C) & - & 7 & - & 27 & - & 60 & 1 & 14 & - & - & - & - & 109 \\
\hline Lepidoptera & - & - & - & - & - & - & - & - & - & - & - & - & - \\
\hline Pyralidae (Sh) & 7 & 139 & 11 & 513 & 11 & 3065 & - & 1288 & - & - & - & 333 & 5367 \\
\hline Allochthonous & 8 & 4 & 6 & 147 & 3 & 199 & 3 & 361 & 8 & 136 & 9 & 138 & 1022 \\
\hline Total & 95 & 3157 & 118 & 3181 & 187 & 5866 & 574 & 6996 & 693 & 5073 & 1505 & 5848 & 33293 \\
\hline
\end{tabular}

*The letters behind the taxa represent the trophic functional group, being: C: collector; Sh: Shredder; G: Generalist, Pr: predator; Sc: scraper; Pa: parasite.

that appears as a rare group. These differences in community composition can be related to the collect methods. While Perera (2010) used core to collect sediments up to $5 \mathrm{~cm}$ deep while in this particular study dip nets were used, being possible to collect bigger organisms that are free at water column such as Belostomatidae, which did not appear at Perera (2010).

The predator and generalist predominance at rice crops are associated to food availability in this environment, once the tillage allowed a recent colonization and food availability. However, after some months with flood irrigation it is possible to realize increases that were already present and new one star appear, such as generalists that appear in greater quantity. These observations are similar for Stenert (2009), when predators and generalists are the dominant trophic group at rice cultivation, along with collectors.

Among the benthic macroinvertebrate found at the rice cultivation, the shredders and scrapers have less participation than in wetlands, probably due 


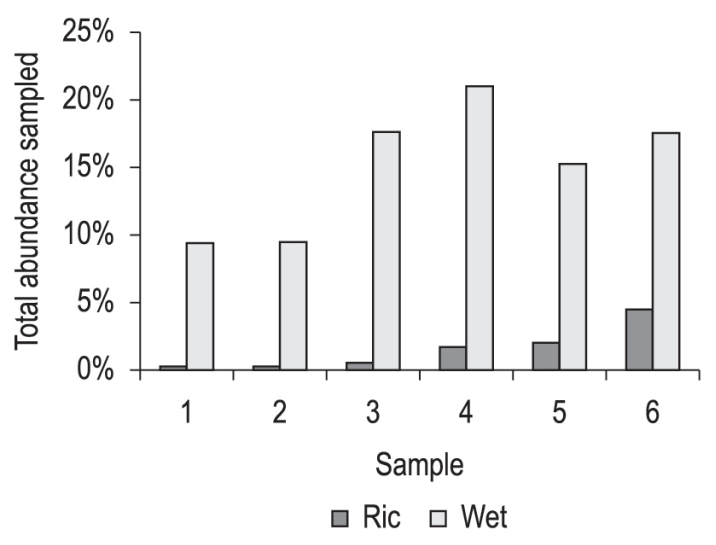

Figure 1. Relative abundance observed at the wetland and rice cultivation relative to total abundance sampled at the study environments.

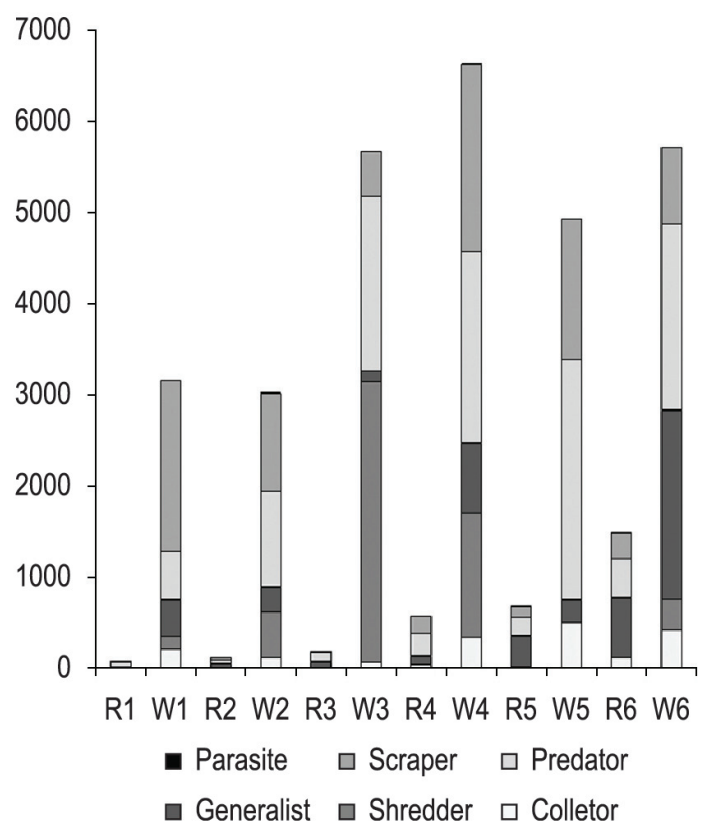

Figure 2. Abundance of trophic functional groups founded at rice cultivarion $(\mathrm{R})$ and wetlands (W) at different sample periods ( 1 and 2 - January, 3 and 4 - February, 5 and $6-$ March).

to organic matter that is not so available at the rice cultivation. Functional groups are aggregated during the irrigation period in rice cultivation, suggesting that the similarities with wetlands can be higher if the water retained inside the rice cultivation area outside the period of cultivation, according purposed by Stenert (2009).

The wetland has more diversity and abundance of benthic macroinvertebrate than rice cultivation, even though the rice cultivation have benthic macroinvertebrates that could help to sustain aquatic communities such as aquatic birds or fish, which feed on site, in the drainage canals or water bodies underlying. It is necessary to study different management practices that can help define the agricultural practices more favorable for the maintenance of functionality of these artificial wetlands.

\section{Acknowledgements}

The authors are grateful to the CAPES scholarship and EMBRAPA for funding for project implementation.

\section{References}

CALLISTO, M., MORENO, P. and BARBOSA, FAR. 2001. Habitat diversity and benthic functional trophic goups at Serra do Cipó, Southeast Brazil. Revista Brasileira de Biologia, vol. 61, no. 2, p. 259-266. http://dx.doi.org/10.1590/S003471082001000200008

CHOMENKO, L. 1997. Impactos negativos do arroz irrigado nos ecossitemas e recursos hídricos. In Anais da XXII Reunião da Cultura do Arroz, 1997. Itajai. p. 68-70.

COPATTI, CE., SCHIRMER, FG. and MACHADO, JVV. 2010. Diversidade de macroivertebrados bentônicos na avaliação da qualidade ambiental de uma microbacia no sul do Brasil. Revista Perspectiva, vol. 34, no. 135, p. 79-91.

COSTA, FlM., OliveirA, A. and CALlisto, M. 2006. Inventory of benthic macroinvertebrates diversity in the Peti Environmental Station Reservoir of Minas Gerais, Brazil. Neotropical Biology and Conservation, vol. 1, no. 1, p. 17-23.

Instituto Riograndense do Arroz - IRGA. 2006. Censo da lavoura de arroz irrigado do Rio Grande do Sul: safra 2004/5. Porto Alegre. Available from: <http://www. irga.rs.gov.br>. Access in: 17 jun. 2013.

ESTEVES, FA. 1998. Fundamentos de limnologia. 2. ed. Rio de Janeiro: Interciência. 602 p.

PERERA, MB. 2010. Estrutura da comunidade de macroinvertebrados bentônicos em arrozais e banhado do Sistema do Canal São Gonçalo. Pelotas: Universidade Federal de Pelotas. 41 p. [Monografia].

PILLAR, VP. and ORLÓCI, L. 1996. On randomization testing in vegetation science: multifactor comparisons of relevé groups. Journal of Vegetation Science, vol. 7, no. 4, p. 585-592. http://dx.doi. org $/ 10.2307 / 3236308$

PINHEIRO, MS. and DIAS, RA. 1998. Levantamento biótico preliminar da área de banhado da Estação Experimental Terras Baixas/Embrapa Clima Temperado, Capão do Leão - RS. Pelotas: Embrapa Clima Temperado. (Documentos, no. 49). 
Ramsar Convention Secretariat. 2006. The Ramsar Convention Manual: a guide to the Convention on Wetlands (Ramsar, Iran, 1971). 4th ed. Gland: Ramsar Convention Bureau. 118 p.

REICE, SR. and WOHLENBERG, M. 1993. Monitoring freshwater benthic macroinvertrates and benthic process: measures for assessment of ecosystem health. London: Chapman \& Hall. 488 p.

SANTOS, EM. 2008. Dinâmica de macroinvertebrados em um lago costeiro do sul do Brasil (Lagoa da Reserva, Mostardas-RS). São Leopoldo: Universidade do Vale do Rio dos Sinos. 40 p. [Dissertação de Mestrado em Biologia].
Sociedade Sul-brasileira de Arroz Irrigado - SOSBAI. 2007. Arroz irrigado: recomendações técnicas da pesquisa para o Sul do Brasil. Pelotas. $154 \mathrm{p}$.

STENERT, C. 2009. Estrutura da comunidade de invertebrados aquáticos em arrozais do Rio Grande do Sul. São Carlos: Centro de Ciências Biológicas e da Saúde, Universidade Federal de Sáo Carlos. 205 p. [Tese de Doutorado em Ecologia e Recursos Naturais].

WINCKLER-SOSINSKI, LTW. 2009. Caracterização da Bacia Hidrográfica Mirim São Gonçalo e o uso dos recursos naturais. Pelotas: Embrapa Clima Temperado. (Documentos, no. 255).

Received: 20 August 2013 Accepted: 26 June 2014 